\title{
ANALISIS PENERAPAN AKUNTANSI KEUANGAN PADA CV. DINAMIKA CIPTA SELARAS KUPANG
}

\author{
Oleh: \\ Jasintha Dessy Tapatfeto*
}

\begin{abstract}
Abstrak
Informasi keuangan yang dibutuhkan oleh pihak internal perusahaan digunakan untuk menilai keberhasilan suatu usaha maupun penetapan suatu kebijakan bagi usaha di masa yang akan datang. CV. Dinamika Cipta Selaras merupakan salah satu perusahaan yang bergerak dalam bidang perdagangan (jual-beli ataupun pengadaan proyek tender) . Berdasarkan prapenelitian, menunjukkan bahwa pihak perusahaan belum melaksanakan proses akuntansi sesuai dengan prinsip akuntansi yang diterima umum. Hal ini membuat kesulitan bagi pimpinan dalam mengambil keputusan untuk pengembangan perusahaan dimasa yang akan datang maupun bagi pihak luar yang mempunyai kepentingan dengan perusahaan. Penelitian ini membantu perusahaan dalam membuat proses akuntansi sehingga dapat diperoleh informasi keuangan yang tepat dan akurat.
\end{abstract}

Kata kunci : Penerapan, Akuntansi Keuangan

*) Jasintha Dessy Tapatfeto ; Dosen Program Studi Akuntansi Sektor Publik Politeknik Negeri Kupang.

\section{PENDAHULUAN}

Setiap kejadian ekonomi dalam suatu perusahaan diperlukan pencatatan laporan keuangan secara rapih dan benar sehingga mampu memberikan gambaran/informasi kepada pihak internal maupun eksternal perusahaan tentang harta kekayaan dan segala hal yang berhubungan dengan perkembangan usaha.

Informasi keuangan yang dibutuhkan oleh pihak internal perusahaan digunakan untuk menilai keberhasilan suatu usaha maupun penetapan suatu kebijakan bagi usaha di masa yang akan datang. Sebaliknya informasi keuangan yang dibutuhkan oleh pihak eksternal digunakan untuk menetapkan kebijakan-kebijakan dalam rangka penanaman modal dan sebagai dasar pengambilan keputusan dalam memberikan pinjaman kepada perusahaan.

$$
\text { Pentingnya pencatatan }
$$
akuntansi secara teratur dan rapi, karena melalui pencatatan maka setiap anggota perusahaan dapat mengetahui dengan jelas berapa jumlah atau banyaknya barang produksi yang dibutuhkan dan berapa besar keuntungan atau kerugian yang dialami perusahaan.Mencermati hal ini, terlihat bahwa peran akuntansi dalam suatu 
perusahaan sangat mendukung terutama bagi manajer keuangan didalam pengambilan keputusan.

Peranan pelaksanakan proses akuntansi yang sesuai dengan prinsip akuntansi yang diterima umum diawali dengan terjadinya transaksi yang dibuktikan dengan adanya dokumen yang digunakan sebagai dasar pencatatan transaksi sekaligus pengolongan kedalam kelompok atau kategori yang berhubungan, kemudian transaksi tersebut digolongkan ke dalam buku jurnal, selanjutnya diringkas dan ditransfer ke dalam buku besar serta dilaporkan dalam bentuk laporan keuangan, sehingga proses akuntansi berakhir dengan penyajian laporan keuangan.

CV. Dinamika Cipta Selaras merupakan salah satu perusahaan yang bergerak dalam bidang perdagangan (jual-beli ataupun pengadaan proyek tender) . Berdasarkan prapenelitian, menunjukkan bahwa pihak perusahaan belum melaksanakan proses akuntansi sesuai dengan prinsip akuntansi yang diterima umum, dalam hal pencatatan yang dilakukan oleh CV.Dinamika Cipta Selaras masih secara manual dan sangat sederhana sekali berupa bukti kwitansi saja, tanpa membuat jurnal maupun buku besar.

Bertolak dari uraian diatas penulis tertarik untuk melakukan penelitian pada CV.Dinamika Cipta Selaras dengan judul Penerapan
Akuntansi Keuangan pada CV. Dinamika Cipta Selaras.

\section{PERUMUSAN MASALAH}

Belum dilaksanakannya proses akuntansi sesuai dengan prinsip akuntansi yang diterima umum, dimana pencatatan yang dilakukan oleh CV.Dinamika Cipta Selaras masih dilakukan secara manual dan sangat sederhana sekali berupa bukti kwitansi saja, tanpa membuat jurnal maupun buku besar. Seharusnya pihak perusahaan sudah bisa menerapkan akuntansi berterima umum.

Berdasarkan latar belakang yang telah diuraikan diatas maka yang menjadi masalah dalam penelitian ini adalah "Bagaimana Penerapan Akuntansi Keuangan pada CV.Dinamika Cipta Selaras Kupang?".

\section{TUJUAN PENELITIAN}

Untuk mengetahui penerapan akuntansi keuangan yang dilakukan oleh CV. Dinamika Cipta Selaras.

\section{KERANGKA BERPIKIR DAN HIPOTESIS}

a. Kerangka berpikir

Berdasarkan uraian yang dikemukakan sebelumnya maka yang menjadi kerangka berpikir dalam penelitian ini dapat penulis sajikan sebagai berikut : 


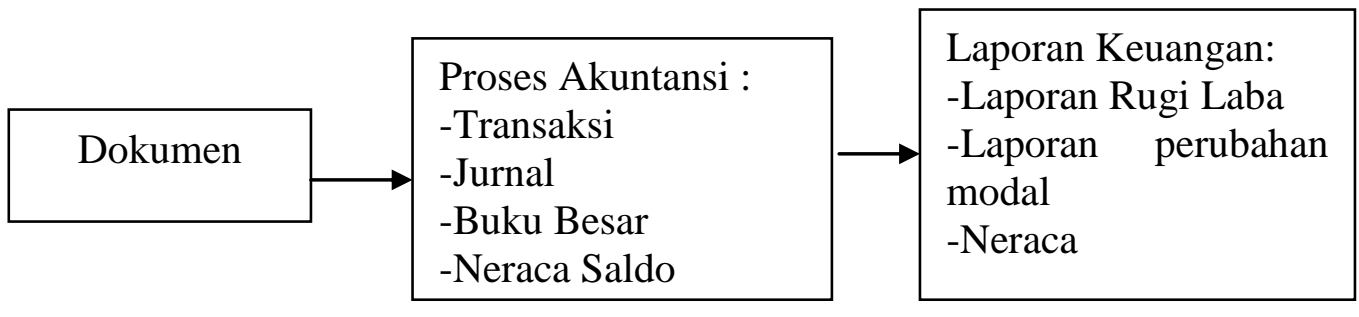

Gambar: 1 Kerangka Berpikir

b Hipotesis

Adapun jawaban sementara yang di angkat untuk menjawab permasalahan dalam hipotesis penelitian ini adalah “ Jika proses akuntansi dilakukan secara baik dan benar maka akan diperoleh informasi keuangan yang tepat dan akurat"

\section{METODE PENELITIAN}

Jenis Data yang digunakan dalam penelitian ini adalah data kualitatif dan data kuantitatif. Sumber data yakni data Primer dan data sekunder. Teknik pengumpulan data dilakukan dengan cara Observasi, Interview dan Dokumentasi. Teknik analisa data yang digunakan dalam penelitian ini adalah deskriptif komparatif (comparative description) yaitu membandingkan antara penerapan akuntansi pada perusahaan dengan penerapan akuntansi berdasarkan prinsip akuntansi yang diterima umum, yang selanjutnya ditarik sebuah kesimpulan.

\section{HASIL PENELITIAN DAN PEMBAHASAN \\ Dalam penerapan akuntansi} perusahan dagang pada CV. Dinamika Cipta Selaras, digunakan transaksi transaksi bulan Juli 2013. Dalam pelaksanakannya proses akuntansi dilakukan dengan menerapkan metode dan prosedur sebagai berikut :

a.Periode akuntansi dimulai 1 Januari sampai 31 Desember.

b. Persediaan dicatat menurut sistem inventarisasi ( sistem periodik /fisik)

c. Penyusutan aktiva tetap dihitung menggunakanmetode garis lurus (Straight Line Method)

1. Data Akuntansi

a. Data Neraca Saldo Awal

Neraca saldo CV. Dinamika Cipta Selaras pada 30 Juli 2013 menunjukan data sebagai berikut:

Tabel 4.2

\section{POLITEKNIK NEGERI KUPANG}

| ISSN 2528-0651 
Neraca Saldo Awal

\begin{tabular}{|l|l|l|l|}
\hline $\begin{array}{c}\text { Nomor } \\
\text { Rekening }\end{array}$ & \multicolumn{1}{|c|}{ Nama Rekening } & Debet & Kredit \\
\hline 101 & Kas & Rp. 35.000.000,- & - \\
\hline 102 & Bank & Rp. 105.709. 957,- & - \\
\hline 103 & Persediaan Barang Dagangan & Rp. 12.000.000 & - \\
\hline 104 & Tanah & Rp. 60.000.000 & - \\
\hline 105 & Gedung & Rp. 90.000.000 & - \\
\hline 106 & Akum. Peny. Gedung & - & Rp. 50.937.500 \\
\hline 107 & Kendaraan & Rp. 140.000.000 & - \\
\hline 108 & Akum. Peny. Kendaraan & - & Rp. 77.250.000,- \\
\hline 109 & Peralatan & Rp. 36.000.000 & - \\
\hline 110 & Akum. Peny. Peralatan & - & Rp. 21. 500.000,- \\
\hline 201 & Hutang Dagang & - & Rp. 2. 580.000,- \\
\hline 301 & Modal & - & Rp. 326.442.457,- \\
\hline & Jumlah & Rp. 478. 709.957,- & Rp. 478. 709. 957,- \\
\hline
\end{tabular}

Sumber : Data diolah, Tahun 2014

2. Transaksi Bulan Agustus Tahun 2013

Dalam aplikasi akuntansi pada CV.

Dinamika Cipta Selaras, penulis

terjadi pada bulan Agustus 2013, transaksi-transaksi yang terjadi menggunakan transaksi-transaksi yang

\begin{tabular}{|c|c|c|}
\hline No & Tanggal & Keterangan \\
\hline 1 & $01-08-13$ & $\begin{array}{l}\text { Membeli Barang Dagangan secara Tunai sebesar Rp.10.000.00 dan Biaya angkutan } \\
\text { pembelian Rp.150.000 }\end{array}$ \\
\hline 2 & $01-08-13$ & Dijual barang dagangan secara tunai sebesar Rp. 2.153 .750 \\
\hline 3 & $02-08-13$ & Dijual barang dagangan secara tunai sebesar Rp. 2.472 .250 \\
\hline 4 & $03-08-13$ & Dijual barang dagangan secara tunai sebesar Rp.2.785.950 \\
\hline 5 & $04-08-13$ & Dijual barang dagangan secara tunai sebesar Rp.1.938.500 \\
\hline 6 & $05-08-13$ & Dijual barang dagangan secara tunai sebesar Rp. 3.105. 250 \\
\hline 7 & $05-08-13$ & Pelunasan hutang kepada cv. putri tunggal sebesar Rp. 2.580 .000 \\
\hline 8 & $06-08-13$ & Membeli barang dagangan dari cv. putri tunggal secara kredit sebesar Rp. 3.500 .000 \\
\hline 9 & 06-08-13 & Dijual barangan dagangan secara tunai sebesar Rp. 2.535 .900 \\
\hline 10 & $07-08-13$ & Dijual barang dagangan secara tunai sebesar Rp. 1.792 .500 \\
\hline 11 & $08-08-13$ & $\begin{array}{l}\text { Membayar pelunasan atas transaksi tanggal } 06 \text { agustus 2013, dan biaya angkutan sebesar } \\
\text { Rp. } 40.000\end{array}$ \\
\hline 12 & $08-08-13$ & Dijual barang dagangan secara tunai sebesar Rp. 2.137 .750 \\
\hline 13 & $09-08-13$ & Dijual barang dagangan secara tunai sebesar Rp. 1. 097.550 \\
\hline 14 & $10-08-13$ & Membayar gaji 7 orang karyawan sebesar Rp. 4. 300.000 \\
\hline 15 & $10-08-13$ & Membayar Rekening ListrikRp. 453.000, air Rp. 65.000 dan telepon Rp. 230.000 \\
\hline 16 & $10-08-13$ & Dijual barang dagangan secara tunai sebesar Rp 2.126 .500 \\
\hline 17 & $11-08-13$ & Membeli barang dagangan dari cv. barokah abadi secara kredit sebesar Rp. 2.500 .000 \\
\hline 18 & $11-08-13$ & Dijual barang daganagan secara tunai sebesar Rp.1.384.000 \\
\hline 19 & $12-08-13$ & Dijual barang dagangan secara tunai sebesar Rp. 2.131 .750 \\
\hline
\end{tabular}




\begin{tabular}{|c|c|c|}
\hline 20 & $13-08-13$ & Dijual barang dagangan secara tunai sebesar Rp. 2. 097.850 \\
\hline 21 & $14-08-13$ & $\begin{array}{l}\text { Membayar utang atas transaksi tanggal } 11 \text { agusutus } 2013 \text { dan biaya angkut pembelian } \\
\text { sebesar Rp. } 40.000\end{array}$ \\
\hline 22 & $14-08-13$ & Dijual barang dagangan secara tunai sebesar Rp. 1.871 .450 \\
\hline 23 & $15-08-13$ & Dijual barang dagangan secara tunai sebesar Rp. 1.537 .900 \\
\hline 24 & $16-08-13$ & Dijual barang dagangan secara tunai sebesar Rp. 2.103 .600 \\
\hline 25 & $17-08-13$ & Dijual barang dagangan secara tunai sebesar Rp. 1.936 .500 \\
\hline 26 & $17-08-13$ & Membeli barang dagangan dari cv. mandiri secara tunai sebesar Rp. 1.200 .000 \\
\hline 27 & $18-08-13$ & Dijual barang dagangan secara tunai sebesar Rp. 3.386 .500 \\
\hline 28 & 19-08-13 & Dijual barang dagangan secara tunai sebesar Rp. 1.692 .250 \\
\hline 29 & $20-08-13$ & Dijual barang dagangan secara tunai sebesra Rp. 2. 093.000 \\
\hline 30 & $21-08-13$ & Membeli barang dagangan dari cv. makro meubel secara kredit sebesar Rp. 3.000 .000 \\
\hline 31 & $21-08-13$ & Dijual barang dagangan secara tunai sebesar Rp. 1.738 .550 \\
\hline 32 & $22-08-13$ & Dijual barang dagangan secara tunai sebesar Rp. 2.281 .750 \\
\hline 33 & $23-08-13$ & Dijual barang dagangan secara tunai sebesar Rp. 2.039 .600 \\
\hline 34 & $24-08-13$ & Membeli barang dagangan dari cv. makro meubel secara kredit sebesar Rp. 2.650.000 \\
\hline 35 & $24-08-13$ & Dijual barang daganagn secara tunai sebesar Rp.1.835.500 \\
\hline 36 & $25-08-13$ & $\begin{array}{l}\text { Membayar utang atas transaksi tanggal } 21 \text { agustus } 2013 \text { dan biaya angkut pembelian } \\
\text { sebesar Rp. } 40.000\end{array}$ \\
\hline 37 & $25-08-13$ & Dijual barang dagangan secara tunai sebesar Rp. 3.842 .950 \\
\hline 38 & $26-08-13$ & Dijual barang dagangan secara tunai sebesar Rp. 1.971 .650 \\
\hline 39 & $27-08-13$ & Dijual barang dagangan secara tunai sebesar Rp. 1.875. 250 \\
\hline 40 & $28-08-13$ & Membayar utang atas transaksi tanggal 24 agusustus dan biaya angkut sebesar Rp. 40.000 \\
\hline 41 & $28-08-13$ & Dijual barang dagangan secara tunai sebesar Rp. 1.058 .300 \\
\hline 42 & $29-08-13$ & Dijual barang dagangan secara tunai sebesar Rp. 985.500 \\
\hline 43 & $30-08-13$ & Membeli barang dagangan dari cv. makro meubel secara kredit sebesar Rp. 3.500 .000 \\
\hline 44 & $30-08-13$ & Dijual barang dagangan secara tunai sebesar Rp. 969.750 \\
\hline 45 & $31-08-13$ & Dijual barang dagangan secara tunai sebesar Rp. 899.550 \\
\hline
\end{tabular}

Sumber : CV. Dinamika Cipta Selaras,Tahun 2013

Data penyesuaian per 31 Agustus 2013, Pembahasan

terdiri dari :

a. Persedian barang dagangan akhir adalah sebesar Rp. 5.200.000

b. Depresiasi gedung disusutkan per tahun dengan taksiran nilai sisa sebesar

Rp. 15.000.000 dan umur ekonomisnya ditaksir 20 tahun.

c. Depresiasi kenderaan disusutkan per tahun dengan taksiaran nilai sisa sebesar Rp. 50.000 .000 dan umur ekonmisnya ditaksir 10 tahun.

d. Depresiasi peralatan disusutkan per tahun dengan taksiran nilai sisa sebesar Rp. 6.000.000 dan umur ekonomisnya ditaksir 5 tahun.
Berdasarkan wawancara, penulis mengetahui bahwa perusahaan belum melakukan pencatatan sesuai proses akuntansi yang diterima umum, Perusahaan hanya mencatat transaksi pada bukti kwintansi saja tanpa melakukan pencatatan pada jurnal, buku besar, neraca saldo, bahkan laporan keuangan pun tidak dibuat sama sekali, sehingga informasi keuangan yang dihasilkan tidak tepat waktu. Hal ini membuat kesulitan bagi pimpinan dalam mengambil keputusan untuk pengembangan perusahaan dimasa yang akan datang maupun bagi pihak luar yang mempunyai kepentingan dengan perusahaan, 
dengan demikian untuk memperoleh suatu laporan keuangan yang baik perlu dilakukan pencatatan dengan mengikuti proses akuntansi yang berlaku.Sebagai sample penulis menggunakan transaksi pada bulan Agustus 2013 untuk membuat proses akuntansi yang dapat diterima secara umum untuk diketahui oleh CV. Dinamika Cipta Selaras dalam pencatatan keuangan.
Kode Rekening

Kode rekening merupakan urutanurutan nomor dari semua rekening yang ada dengan tujuan untuk mempermudah dalam pencarian nomor rekening, dimana nomor rekening yang dibuat harus sesuai dengan urutan yang baku yakni, harta, utang, modal, pendapatan atau penjualan dan biaya. Untuk lebih jelas dapat dilihat sebagai berikut:

Tabel. 4.3

Nama dan Kode Rekening

\begin{tabular}{|c|l|c|l|}
\hline No & \multicolumn{1}{|c|}{ Kode Rekening } & No Rek & \multicolumn{1}{|c|}{ Nama Rekening } \\
\hline 1 & AKTIVA & 101 & Kas \\
\hline & & 102 & Bank \\
\hline & & 103 & Persediaan barang dagangan \\
\hline & & 104 & Tanah \\
\hline & & 105 & Gedung \\
\hline & & 106 & Akumulasi penyusutan gedung \\
\hline & & 107 & Kendaraan \\
\hline & & 108 & Akumulasi penyusutan kendaraan \\
\hline & & 109 & Peralatan \\
\hline 2 & Kewajiban & 110 & Akumulasi Penyusutan Kenderaan \\
\hline 3 & Modal & 201 & Hutang dagang \\
\hline 4 & Pendapatan & 301 & Modal \\
\hline 5 & Harga pokok penjualan & 401 & Pendapatan/Penjualan \\
\hline & & 501 & Harga Pokok Penjualan \\
\hline 6 & Biaya & 502 & Pembelian Barang Dagangan \\
\hline & & 601 & Biaya gaji \\
\hline & & 602 & Biaya listrik, air dan telepon \\
\hline & & 603 & Biaya angkut pembelian \\
\hline & & 604 & Biaya penyusutan gedung \\
\hline & & 605 & Biaya penyusutan kendaraan \\
\hline & & 606 & Biaya penyusutan peralatan \\
\hline
\end{tabular}

Sumber : Data diolah, Tahun 2014

Berdasarkan uarain diatas

maka langkah selanjutnya adalah melakukan proses akuntansi yang sebenarnya sesuai dengan prinsip-

prinsip akuntansi yang lazim sehingga menghasilkan sebuah informasi akuntansi yang benar- benar akurat dan dapat dipertanggungjawabkan. 
Tabel. 4.4

Jurnal Umum Halaman 1

\begin{tabular}{|c|c|c|c|c|c|}
\hline \multicolumn{2}{|c|}{ Tgl } & \multirow[t]{2}{*}{ Keterangan } & \multirow{2}{*}{$\begin{array}{c}\text { No Rek } \\
502\end{array}$} & \multirow{2}{*}{$\begin{array}{c}\begin{array}{c}\text { Debet } \\
(\mathrm{Rp})\end{array} \\
10.000 .000\end{array}$} & \multirow{2}{*}{$\begin{array}{c}\begin{array}{c}\text { Kredit } \\
\text { ( Rp) }\end{array} \\
-\end{array}$} \\
\hline $\begin{array}{l}\text { Agust } \\
2013\end{array}$ & 1 & & & & \\
\hline & & Biaya Angkutan & 603 & 150.00 & - \\
\hline & & Kas & 101 & - & 10.150 .000 \\
\hline & 1 & Kas & 101 & 2.153 .750 & - \\
\hline & & Penjualan & 401 & - & 2.153 .750 \\
\hline & 2 & Kas & 101 & 2.427 .250 & - \\
\hline & & Penjualan & 401 & - & 2.427 .250 \\
\hline & 3 & Kas & 101 & 2.785 .950 & - \\
\hline & & Penjualan & 401 & - & 2.785 .950 \\
\hline & 4 & Kas & 101 & 1.938 .500 & - \\
\hline & & Penjualan & 401 & - & 1.938 .500 \\
\hline & 5 & Kas & 101 & 3.015 .250 & - \\
\hline & & Penjualan & 401 & - & 3.015 .250 \\
\hline & 5 & Hutang Dagang & 201 & 2.580 .000 & - \\
\hline & & Kas & 101 & - & 2.580 .000 \\
\hline & 6 & Pembelian & 502 & 3.500 .000 & - \\
\hline & & Hutang Dagang & 201 & - & 3.500 .000 \\
\hline & 6 & Kas & 101 & 2.539 .900 & - \\
\hline & & Penjualan & 401 & - & 2.539 .900 \\
\hline & 7 & Kas & 101 & 1.792 .500 & - \\
\hline & & Penjualan & 401 & - & 1.792 .500 \\
\hline & 8 & Hutang Dagang & 201 & 3.500 .000 & - \\
\hline & & Biaya angkutan & 603 & 40.000 & - \\
\hline & & Kas & 101 & - & 3.540 .000 \\
\hline & 8 & Kas & 101 & 2.137 .750 & - \\
\hline & & Penjualan & 401 & - & 2.137 .750 \\
\hline & 9 & Kas & 101 & 1.097 .550 & - \\
\hline & & Penjualan & 401 & - & 1.097 .550 \\
\hline & 10 & Biaya Gaji & 601 & 4.300 .000 & - \\
\hline & & Kas & 101 & - & 4.300 .000 \\
\hline & 10 & Biaya listrk, air dan telepon & 602 & 748.000 & - \\
\hline & & Kas & 101 & - & 748.000 \\
\hline & 10 & Kas & 101 & 2.126 .500 & - \\
\hline & & Penjualan & 401 & - & 2.126 .500 \\
\hline & 11 & Pembelian & 502 & 2.500 .000 & - \\
\hline & & Hutang dagang & 201 & - & 2.500 .000 \\
\hline & 11 & Kas & 101 & 1.384 .000 & - \\
\hline & & Penjualan & 401 & - & 1.384 .000 \\
\hline & 12 & Kas & 101 & 2.131 .750 & - \\
\hline & & Penjualan & 401 & - & 2.131 .750 \\
\hline & 13 & Kas & 101 & 2.097 .850 & - \\
\hline
\end{tabular}


JURNAL AKUNTANSI, KEUANGAN DAN AUDIT

\begin{tabular}{|c|c|c|c|c|}
\hline & Penjualan & 401 & - & 2.097 .850 \\
\hline 14 & Hutang dagang & 201 & 2.500 .000 & - \\
\hline & Biaya angkutan & 603 & 40.000 & - \\
\hline & Kas & 101 & - & 2.540 .000 \\
\hline 14 & Kas & 101 & 1.871 .450 & - \\
\hline & Penjualan & 401 & - & 1.871 .450 \\
\hline 15 & Kas & 101 & 1.537 .900 & - \\
\hline & Panjualan & 401 & - & 1.537 .900 \\
\hline 16 & Kas & 101 & 2.103 .600 & - \\
\hline & Penjualan & 401 & - & 2.103 .600 \\
\hline 17 & Kas & 101 & 1.936 .500 & - \\
\hline & Penjualan & 401 & - & 1.936 .500 \\
\hline 17 & Pembelian & 502 & 1.200 .000 & - \\
\hline & Kas & 101 & - & 1.200 .000 \\
\hline 18 & Kas & 101 & 3.386 .500 & - \\
\hline & Penjualan & 401 & - & 3.386 .500 \\
\hline 19 & Kas & 101 & 1.692 .250 & - \\
\hline & Penjualan & 401 & - & 1.692 .250 \\
\hline 20 & Kas & 101 & 2.093 .000 & - \\
\hline & Penjualan & 401 & - & 2.903 .000 \\
\hline 21 & Pembelian & 502 & 3.000 .000 & - \\
\hline & Hutang dagang & 201 & - & 3.000 .000 \\
\hline 21 & Kas & 101 & 1.738 .550 & - \\
\hline & Penjualan & 401 & - & 1.738 .550 \\
\hline 22 & Kas & 101 & 2.281 .750 & - \\
\hline & Penjualaan & 401 & - & 2.281 .750 \\
\hline 23 & Kas & 101 & 2.039 .600 & - \\
\hline & Penjualan & 401 & - & 2.039 .600 \\
\hline 24 & Pembelian & 502 & 2.650 .000 & - \\
\hline & Hutang dagang & 201 & - & 2.650 .000 \\
\hline 24 & Kas & 101 & 1.835 .500 & - \\
\hline & Penjualan & 401 & - & 1835.500 \\
\hline 25 & Hutang Dagang & 201 & 3.000 .000 & - \\
\hline & Biaya Angkut & 603 & 40.000 & - \\
\hline & Kas & 101 & - & 3.040 .000 \\
\hline 25 & Kas & 101 & 3.842 .950 & - \\
\hline & Penjualan & 401 & - & 3.842 .950 \\
\hline 26 & Kas & 101 & 1.971 .650 & - \\
\hline & Penjualan & 401 & - & 1.971 .650 \\
\hline 27 & Kas & 101 & 1.875 .250 & - \\
\hline & Penjualan & 401 & - & 1.875 .250 \\
\hline
\end{tabular}




\begin{tabular}{|c|c|c|c|c|c|}
\hline & 28 & Hutang dagang & 201 & 2.650 .000 & - \\
\hline & & Biaya angkutan & 603 & 40.000 & - \\
\hline & & Kas & 101 & - & 2.690 .000 \\
\hline & 28 & Kas & 101 & 1.058 .300 & - \\
\hline & & Penjualan & 401 & - & 1.058 .300 \\
\hline & 29 & Kas & 101 & 982.500 & - \\
\hline & & Penjualan & 401 & - & 982.500 \\
\hline & 30 & Pembelian & 502 & 3.500 .000 & - \\
\hline & & Hutang Dagang & 201 & - & 3.500 .000 \\
\hline & 30 & Kas & 101 & 969.750 & - \\
\hline & & Penjualan & 401 & - & 969.750 \\
\hline & 31 & Kas & 101 & 899.550 & - \\
\hline & & Penjualan & 401 & - & - \\
\hline & & TOTAL & & $\begin{array}{c}\text { Rp.105.716.20 } \\
0\end{array}$ & Rp. 105.761.200 \\
\hline
\end{tabular}

Sumber : Data diolah Tahun 2014

b. Buku Besar

Setelah membuat jurnal maka langkah selanjutnya adalah memposting semua rekening yang ada di jurnal ke dalam buku besar. Bentuk buku besar yang penulis gunakan adalah buku besar bentuk 3 kolom.

c. Neraca saldo
Setelah memposting semua rekening ke dalam buku besar maka langkah selanjutnya adalah membuat neraca saldo, gunanya adalah menguji kesamaan antara sisi debet dan kredit dan juga untuk mempermudah penyusunan laporan keuangan.

Tabel. 4.27

Neraca Saldo.CV. Dinamika Cipta Selaras Agustus 2013

\begin{tabular}{|l|c|c|}
\hline \multicolumn{1}{|c|}{ Nama Rekening } & Debet & Kredit \\
\hline Kas & 66.088 .050 & - \\
\hline Bank & 105.709 .957 & - \\
\hline Persediaan barang dagangan & 12.000 .000 & - \\
\hline Tanah & 60.000 .000 & 50.937 .500 \\
\hline Gedung & 90.000 .000 & - \\
\hline Akumulasi Penyusutan Gedung & - & 77.250 .000 \\
\hline Kendaraan & 140.000 .000 & - \\
\hline Akumulasi Penyusutan Kendaraan & - & 21.500 .000 \\
\hline Peralatan & 36.000 .000 & 3.500 .000 \\
\hline Akumulasi Penyusutan Peralatan & - & 326.442 .457 \\
\hline Hutang Dagang & - & 61.876 .050 \\
\hline Modal & - & - \\
\hline Penjualan & - & 26.350 .000 \\
\hline Pembelian & & \\
\hline
\end{tabular}

\section{POLITEKNIK NEGERI KUPANG}




\begin{tabular}{|l|c|c|}
\hline Biaya Gaji & 4.300 .000 & - \\
\hline Biaya Listrik,Air dan Telepon & 748.000 & - \\
\hline Biaya Angkut Pembelian & 310.000 & - \\
\hline Jumlah & 541.506 .007 & 541.506 .007 \\
\hline
\end{tabular}

Sumber: Data diolah Tahun 2014

Tabel. 4.28

Jurnal Penyesuaian

\begin{tabular}{|c|c|c|c|c|c|}
\hline \multicolumn{2}{|l|}{$\mathrm{Tgl}$} & Keterangan & Ref & Debet & Kredit \\
\hline \multirow[t]{14}{*}{ Agust 2013} & 31 & Harga Pokok Penjualan & 501 & 12.000 .000 & - \\
\hline & & Persedian Barang Dagangan & 103 & - & 12.000 .000 \\
\hline & 31 & Harga Pokok Penjualan & 501 & 26.350 .000 & \\
\hline & & Pembelian & 502 & & 26.350 .000 \\
\hline & 31 & Harga Pokok Penjualan & 501 & 310.000 & \\
\hline & & Biaya Angkut Pembelian & 603 & & 310.000 \\
\hline & 31 & Persedian Barang Dagangan & 103 & 5.200 .000 & - \\
\hline & & Harga Pokok Penjualan & 501 & - & 5.200 .000 \\
\hline & 31 & Biaya Penyusutan Gedung & 604 & 312.5000 & \\
\hline & & Akum. Penyu. Gedung & 107 & & 312.500 \\
\hline & 31 & Biaya Penyusutan Kendaraan & 605 & 750.000 & \\
\hline & & Akum. Penyu. Kendaraan & 108 & & 750.000 \\
\hline & 31 & Biaya Penyusutan Peralatan & 606 & 500.000 & \\
\hline & & Akum. Penyu. Peralatan & 110 & & 500.000 \\
\hline
\end{tabular}

Sumber : Data diolah Tahun 2014

a. Neraca Lajur

Berdasarkan buku besar yang telah dibuat sebelumnya, maka dapat menyusun neraca lajur dengan terlebih dahulu membuat menghitung saldo masing-masing kemudian di posting ke dalam kolom neraca lajur bagian neraca saldo. Berikut ini neraca lajur yang dibuat CV. Dinamika Cipta Selaras sebagai berikut: 
Tabel 4.29

Neraca Lajur. CV. Dinamika Cipta Selaras Agustus 2013

\begin{tabular}{|c|c|c|c|c|c|c|c|c|c|c|}
\hline \multirow{2}{*}{ Nama perkiraan } & \multicolumn{2}{|c|}{ Neraca Saldo } & \multicolumn{2}{|c|}{ Penyesuaian } & \multicolumn{2}{|c|}{ NSSD } & \multicolumn{2}{|c|}{ Rugi/Laba } & \multicolumn{2}{|c|}{ Neraca } \\
\hline & Debet & Kredit & Debet & Kredit & Debet & Kredit & Debet & Kredit & Debet & Kredit \\
\hline Kas & 66.088 & - & - & - & 66.088 & - & - & - & 66.088 & - \\
\hline Bank & 105.709. & & & & 105.709 & & & & 105.709 & \\
\hline Persediaan Brg Dagangan & 12.000 & - & 5.200 & - & 12.000 & - & - & - & 5.200 & - \\
\hline Tanah & 60.000 & - & - & - & 60.000 & - & - & - & 60.000 & - \\
\hline Kendaraan & 140.000 & - & - & & 140.000 & - & - & - & 140.000 & - \\
\hline Akum. Penyu. Kendaraan & 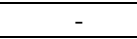 & 77.250 & - & 750 & - & 78.000 & - & - & - & 78.000 \\
\hline Gedung & 90.000 & - & - & - & 90.000 & - & - & - & 90.000 & - \\
\hline Akum. Penyu Gedung & - & 50.937 & - & 312 & - & 51.250. & - & - & - & 51.250 \\
\hline Peralatan & 36.000 & & & & 36.000 & & & & 36.000 & \\
\hline Akum. Penyu. Peralatan & & 21.500 & & 500 & & 22.000 & & & & 22.000 \\
\hline Hutang Dagang & & 3.500 & & & & 3.500 & & . & & 3.500 \\
\hline Modal & - & 326.442 & - & - & - & 326.442 & - & - & - & 326.441 \\
\hline Penjualan & 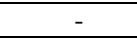 & 61.876 & - & - & - & 61.876 & - & 61.876 & - & - \\
\hline Pembelian & 26.350 & & & 26.350 & & & & & & \\
\hline Biaya Gaji & 4.300 & - & - & - & 4.300 & - & 4.300 & - & - & - \\
\hline Biaya Listrik, Air \& Telp & 748 & - & - & - & 748 & - & 748 & - & - & - \\
\hline Biaya angkutan & 310 & - & - & 310. & - & - & & - & - & - \\
\hline Jumlah & 541.506. & 541.506. & - & - & - & - & - & - & - & - \\
\hline Harga Pokok Penjualan & & & 12.000 & & 12.000 & 5.200 & 12.000 & 5.200 & - & - \\
\hline & & & 26.350 & & & 26.350 & 26.350 & & & \\
\hline & & & 310 & - & 310 & & & - & - & - \\
\hline Biaya Penyu. Gedung & & & 312 & - & 312 & 312 & & - & - & - \\
\hline Biaya penyusutan Kend. & & & 750 & & & 750 & 750 & & & \\
\hline Biaya Peny. Peralatan & & & 500 & & & 500 & 500 & & & \\
\hline
\end{tabular}

21 POLITEKNIK NEGERI KUPANG

| ISSN 2528-0651 


\begin{tabular}{|c|c|c|c|c|c|c|c|c|}
\hline Jumlah & 45.422 & 45.422 & 548.268 & 548.268 & 45.270 & 67.076 & 502.998 & 481.192 \\
\hline Laba sementara & & & & & 21.805 & & & 21.805 \\
\hline Jumlah & & & & & 67.076 & 67.076 & 502.998 & 502.998 \\
\hline
\end{tabular}

Sumber : Data diolah Tahun 2014 
b. Laporan Keuangan Berdasarkan neraca lajur yang telah dibuat untuk CV. Dinamika Cipta Selaras maka dapat disusun laporan keuangan yang terdiri dari laporan laba/rugidalam bentuk miltiple step, laporan perubahan modal dan neraca dalam bentuk $\mathrm{T}$ (Skonto) untuk periode 31 agustus 2013.

Laporan-laporan tersebut dapat dilihat sebagai berikut :

Tabel 4.30

\section{Laporan Rugi/Laba. CV. Dinamika Cipta Selaras Agustus 2013}

\begin{tabular}{|l|l|l|l|}
\hline Penjualan & & & Rp. 61.876 .050 \\
\hline Harga pokok Penjualan : & & & \\
\hline Persedian Awal & Rp. 26. 350.000 & Rp. 12.000 .000 & \\
\hline Pembelian & Rp. 310.000 & & \\
\hline Biaya angkut pembelian & & Rp. 26.660 .000 & \\
\hline & & Rp. 38.660 .000 & \\
\hline Harga pokok barang tersedia untuk dijual & & Rp. 5.200 .000 & \\
\hline Persedian Akhir & & & Rp. 33.460.00 \\
\hline Harga pokok penjualan & & & Rp. 28.416 .050 \\
\hline Laba Kotor & & & \\
\hline Biaya - biaya & & Rp. 4.300 .000 & \\
\hline Biaya Gaji & & Rp 748.000 & \\
\hline Biaya listrik & & Rp. 312.500 & \\
\hline Biaya penyusutan gedung & & Rp.750.000 & \\
\hline Biaya penyusutan kenderaan & & Rp. 500.00 & \\
\hline Biaya penyusutan peralatan & & & Rp. 6.610 .500 \\
\hline Total & & & Rp. 21.805 .550 \\
\hline Laba bersih sebelum pajak & & & \\
\hline
\end{tabular}

Sumber : Data diolah Tahun 2014

Tabel 4.31.

Laporan Perubahan Modal. CV. Dinamika Cipta Selaras Agustus 2013

\begin{tabular}{|l|l|}
\hline Modal awal & Rp. 326.442.457 \\
\hline Laba bersih & Rp. 21.805.550 \\
\hline Modal akhir 31 Agustus & Rp. 348.248.007 \\
\hline
\end{tabular}

Sumber : Data diolah Penulis, Tahun2014

Tabel 4.32

Neraca. CV. Dinamika Cipta SelarasTahun 2013

\begin{tabular}{|l|l|l|l|}
\hline \multicolumn{2}{|c|}{ Aktiva } & \multicolumn{2}{c|}{ Pasiva } \\
\hline Aktiva lancar : & Rp. 66.088.000 & Hutang Dagang & Rp. 3.500.000 \\
\hline Kas & Rp. 105.709.957 & Jumlah kewajiban & Rp. 3.500.000 \\
\hline Bank & Rp. 5.200.000 & & \\
\hline Pers Brg. Dagangan & Rp.226.998.007 & & Rp. 348.248.007 \\
\hline Jml aktiva lancar & Rp. 60.000.000 & Modal : & Rp. 348.248.007 \\
\hline Aktiva tetap : & Rp. 140.000.000 & Jumlah Modal & \\
\hline Tanah & Rp. 78.000.000 & & \\
\hline Kendaraan & Rp.90.000.000 & & \\
\hline Akum penyu. Kendaraan & & \\
\hline Gedung
\end{tabular}

\section{POLITEKNIK NEGERI KUPANG}




\begin{tabular}{|l|l|l|l|}
\hline Akum penyu gedung & Rp. 51.250 .000 & & \\
\hline Peralatan & Rp. 36.000 .000 & & \\
\hline Akumulasi penyu. Peralatan & Rp. 22.000 .000 & & \\
\hline Jml aktiva tetap & Rp. 124.750 .000 & & \\
\hline Total Aktiva & Rp 351.748 .007 & Total Pasiva & Rp. 351.748.007 \\
\hline
\end{tabular}

Sumber : Data diolah Tahun 2014

\section{KESIMPULAN DAN SARAN}

\section{A. Kesimpulan}

Berdasarkan hasil dan pembahasan dalam bab terdahulu, maka penulis berkesimpulan bahwa:

1. Perusahaan CV. Dinamika Cipta Selaras didalam melakukan kegiatan manajemen belum melaksanakan proses akuntansi yang diterima secara umum yang diperlukan oleh pihak ekstern maupun pihak interen.

2. Perusahaan CV. Dinamika Cipta Selaras tidak mengetahui laba sesungguhnya yang diperoleh pada periode akuntansi karena belum menerapkan akuntansi sesuai standar yang diterima secara umum dalam pencatatan keuangan.

3. Berdasarkan penyusunan laporan keuangan pada CV. Dinamika Cipta Selaras Kupang diketahui bahwa pada bulan Agustus 2013CV. Dinamika Cipta Selaras Kupang memperoleh Laba sebesar Rp.21.805.550 sedangkan posisi neraca menghadirkan nilai Aktiva sebesar Rp.351.748.007, Hutang sebesar Rp.3.500.000 dan Modal sebesar Rp.348.248.007.

\section{B. Saran}

Berdasarkan beberapa kesimpulan diatas, maka penulis menyarankan bahwa :

1. Pencatatan keuangan harus menggunakan standar akuntansi yang diterima umum yang dimulai dari adanya dokumen transaksi, jurnal, buku besar, neraca lajur, dan laporan keuangan.

2. Perusahaan CV. Dinamika Cipta Selaras setiap terjadinya transaksi keuangan sebaiknya dicatat dalam buku harian atau jurnal umum.

3. Perusahaan CV. Dinamika Cipta Selaras jika ingin menyediakan informasi keuangan yang akurat dalam kaitannya dengan perencanaan dan pengambilan keputusan usaha diharapkan dapat menerapkan prinsip-prinsip akuntansi yang standar atau standar akuntansi keuangan yang diterima umum.

\section{DAFTAR PUSTAKA}

Alwi, dkk. 2005. Kamus Besar Bahasa Indonesia. Departemen Pendidikan

Nasional. Balai Pustaka: Jakarta. 
Arikunto dan Suharsimi. 2002. Prosedur Penelititan Suatu Pendekatan Praktek. Penerbit Rineka Cipta Indonesia: Yogyakarta.

Baridwan, Zaky. 2004. Intermediate Acounting. Edisi 8. Penerbit BPFE: Yogyakarta.

Djarwanto. 2005. Pokok-pokok Analisa Laporan Keuangan. BPFE: Yogyakarta.

Kasmir. 2008. Analisis Laporan Keuangan. Raja Grafindo Persada: Jakarta.

Kuncoro. 2003. Prosedur Penelititan Suatu Pendekatan Praktek. Penerbit Rineka Cipta Indonesia: Yogyakarta. Munawir, S. 2002. Analisis Laporan Keuangan. Edisi Keempat Liberty:
Yogyakarta.

2004. Analisis Laporan

Keuangan. Edisi Keempat Liberty: Yogyakarta.

2007. Analisis Laporan

Keuangan. Edisi Keempat Liberty: Yogyakarta.

Riyanto. 2000. Dasar-Dasar Pembelanjaan Perusahaan. Edisi Keempat Cetakan Ketujuh. Yogyakarta: BFFE. 2001 Dasar-Dasar Pembelanjaan Perusahaan. Edisi Keempat Cetakan Ketujuh. Yogyakarta: BFFE.

Syahrul. 2000. Akuntansi Manajemen. Rineka Cipta: Jakarta. 